\title{
HET SAOE'SCHE DOODENOFFER EN DE MASKERADE.
}

\author{
(Met af beeldingen).
}

DOOR J. FORTGENS.

De meeste dorpen in het distrikt Saoe ' zijn het geheele jaar onbewoond. Het is een traditioneele gewoonte, dat de bewoners slechts eenmaal per jaar in hun dorp terugkeeren en daar eenige weken verblijven, teneinde het gemeenschappelijk doodenfeest te vieren, terwijl zij overigens verblijf houden in hun z. g. dóusu of huizen in de tuinen, een soort van "buitenverblijven». Het is een vreemd gezicht, wanneer men die verlaten dorpen doortrekt. Men ziet dan geen levend wezen. De huizen waaraan de hand niet gehouden wordt, zien er meest gehavend uit en de verdroogde, vuilgeworden arenpalm-franjes, versieringen van het voorgaande doodenfeest, welke blijven hangen om de dorp- en geestentempels, totdat zij verwisseld worden bij het volgend feest, geven het geheel een nog sçhunniger aanzien. De dakbedekking vertoont ettelijke gaten. De bamboe-gastenbank op de voorgaanderij is door wind en regen schier verteerd. De afvoergoten rondom de woningen zijn met den grond gelijk geworden, zoodat het hemelwater vrijen toegang heeft en daarbinnen een vochtige, duffe lucht verspreidt. Het onkruid is dan hoog tegen de huizen opgegroeid en het paadje, dat naar den ingang van het dorp leidt, is bijna geheel verdwenen. Allen wonen dan in de tuinen, waar in den regel goedgebouwde woningen zijn opgezet, een twee- of drietal naast elkander.

$\mathrm{Na}$ afloop van den rijstoogst begint men er over te denken

1 Gelegen op de westkust van Halemahera, tusschen de distrikten Gamkonora (noordelijk) en Djailolo (zuidelijk). De stam der Saoeërs wordt in tweeën verdeeld. Men makkt onderscheid tusschen de bewoners van de dji'o (baai van Saoe) en de Talai ma ngowa'a (Talaiërs). De eersten spreken hun taal uit met de zachte medeklinkers $\mathrm{g}, \mathrm{b}, \mathrm{dj}$; de anderen met $\mathrm{k}, \mathrm{p}, \mathrm{tj}$. B.v. gágama, (koorts) kákama; bobóngolo, (wang) popóngolo; módjongo, (vreezen) mótjongo, enz. Tot de g-sprekers behooren de dorpen, die rondom de baai (dji'o) gelegen zijn; tot de k-sprekers de dorpen Talai, Balisóana; Idam, Taboso, Golo, Gamómenge, Gamsungi, Gampálara en Gamdólara. 
naar het dorp terug te keeren, teneinde maatregelen te nemen voor het ophanden zijnd doodenfeest. Dan begint de groote schoonmaak. Met vereènde krachten gaan de vrouwen onkruid wieden, toebereidselen maken voor de uitgebreide maaltijden, terwijl de mannen druk in de weer zijn hun woningen te herstellen en die in te richten voor de ontvangst der gasten. Is alles gereed, dan vergaderen de volwassen mannen en overleggen met elkaar, op welken dag men met het djini-offer zal aanvangen. Gezamenlijk herstellen de mannen dan ook de kaseba, de verblijfplaats van den djini (Tern. kokiroba). De kaseba is een huis op palen, waarin zich het meubilair van den djini (een goede beschermgeest) bevindt, nl. een tafel en eenige banken, ook wel stoelen, meestal in miniatuurvorm, terwijl een ruime dansvloer van opengespleten bamboe is aangebracht om den djini-dans te kunnen uitvoeren. De kaseba en de sasadu (dorpstempel, e. s. v. gemeentehuis; afb. 11) worden aan de open zijden omhangen met guirlandes van gespouwen, nog niet ontplooide bladeren van den arenpalm, genaamd wowe. Het uitgestorven dorp van eenige weken te voren is dan in groote bedrijvigheid herschapen. De vrouwen beijveren zich groote hoeveelheden rijst te stampen, suikerriet te persen en tot stroop te koken, terwijl de mannen op jacht en naar het strand zijn om de noodige hoeveelheid visch op te koopen. Is alles gereed om een feest van 5, 7 of 9 dagen te kunnen vieren, dan wordt het feest geopend op de volgende wijze.

Tegen 12 uur of na twaalven, al naar het strand dichter bij of verderaf gelegen is, stelt zich een processie op om de z.g. sóudu (medicijn) te gaan halen, ten behoeve van degenen, die den djini-dans aan den avond van dien eersten dag en volgende dagen zullen uitvoeren. Men noemt dezen tocht útu'u o sóudu, (medicijn oogsten). Aan het hoofd der processie stelt zich op de kalifa, gekleed in een lang, wit hemd en getooid met een witten hoofddoek. In de linkerhand houdt hij een schild (taitaini) en in de rechter een lang hakmes (kole). Achter den kalifa loopen de trom- en bekkenslagers en een guru met een rotanstok in de hand. Achter dezen een vrouw, die de opdracht heeft de te plukken bladeren en wortels voor de "medicijn» te verzamelen. Dan volgen eenige murid (leerlingen), die eenige bamboe-watervaten dragen, teneinde die met zeewater te vullen en achter dezen weer eenige vrouwen, die sirih-pinangdoozen Dl. 68 
dragen, terwijl de rij gesloten wordt door een goeroe, die met een speer (saku-saku) gewapend is om, zooals men zegt, de processie te beschermen. De stoet zet zich in beweging en op de maat van de eentonige trom- en gongslagen marcheert men het dorp uit. Gekomen aan de boomen en struiken, welke de namen dragen van galoba, gofasa, sápana, ngáduru, domóala, lage-lage enz., prevelt de kalifa eenige onverstaanbare woorden en slaat de goeroe die achter den kalifa loopt, met zijn rotanstok de bladeren af, terwijl de vrouw achter hem deze opraapt. Verzamelt zij van elken boom of struik slechts 5 bladeren, dan zal het 5 dagen walenge (doodenfeest) zijn; 7 bladeren, 7 dagen en 9 bladeren, 9 dagen. Heeft zij die bladeren verzameld, dan gaat de stoet verder naar het strand en naar den tuin om zeewater en ritja gofu (een klein soort spaansche peper), te halen; alweer zooveel stuks als de dagen van het feest zullen duren. Daarna keert men in dezelfde volgorde, maar onder gewijzigden trom- en gongslag, naar het dorp terug, waar men door de achtergeblevenen met oorverdoovende trom- en gongslagen in de kaseba ontvangen wordt. Gedurende de volgende 5, 7 of 9 nachten van het feest, mag de trom geen oogenblik in rust zijn, zoodat de trom- en gongslagers elkander voortdurend afwisselen.

De aangekomen processie zet zich op een rij in de kaseba en het eerste ceremoniëel dat men verricht, is het z. g. léoto banju, d. i. het "neerzetten van het water», de medicijn, welke men zooeven plechtig van den zeekant gehaald heeft. De kalifa zet nu naast zich een bord met brandend houtskool, waarop wierook gebrand wordt, en een grooten schotel. Deze schotel wordt nu gevuld met zeewater. De vrouw, die zooeven de bladeren moest oplezen, wrijft er eenige tusschen de handen fijn en doet die in het zeewater, terwijl de kalifa een jonge bloemkolf van den areekpalm ook in dien schotel legt om straks daarmede de murid (leerlingen) te bestrijken. Ook plaatst hij naast zich een kommetje, gevuld met gekruide kokosolie; in die kokosolie legt hij een bloem van den bekenden tjempakaboom. Van een bord, waarop limoenen liggen (van een bepaalde soort genaamd tigila, Mol.-Mal. lemon soeangi), neemt hij een vrucht, blaast erop, bestrijkt deze met de gekruide kokosolie, houdt de vrucht boven den wierook en geeft haar door aan degenen, die straks den djini-dans zullen uitvoeren. 
Ieder hunner neemt de vrucht, blaast erop en zegt: oes, oes, oes! Bij den kalifa teruggekomen, neemt hij een mes, beblaast dat en snijdt de vrucht doormidden. Heeft hij het ongeluk een der pitten door te snijden, dan is dat een voorteeken, dat binnenkort een der goeroes sterven zal. $\mathrm{Nu}$ worden ook de andere lemoenen doorgesneden, uitgeperst in den grooten schotel zeewater, vermengd met de op dien dag verzamelde wortels, bladeren en spaanschen peper, waarbij nog een weinig azijn (verzuurd sap van den arenpalm) gevoegd wordt en dan is de medicijn gereed en in voldoende hoeveelheid aanwezig om den boozen geest te verdrijven en den djini te laten invaren. Daarna neemt de kalifa een takje bladeren, heft dat omhoog met het aangezicht naar de verblijfplaats van den djini gericht en begint te niati, d. i. den djini aan te roepen en zegt - in grammatikaal-slordige zinnen - het volgende:

Saro, saro, saro! ibarabuata! Ma tjimi to ma Batawi-isa, tudu to ma olana Batja'a, waro ma ngaleuwa, ngadolo ma ngaleuwa. Situadi to ma olana Todore, waro ma ngaleuwa, liliani ma nga'unuwa. Sitede to ma olana Tarinate, liliani ma nga'unuwa, waro ma ngaleuwa. Sitede to ma dji'o lamo-lamo'o, Talai ma kam rata re dji'o romotoa, waro ma ngaleuwa, liliani ma nga'unuwa, ngadolo ma batiuwa. Sidipo ngoi ari baba re ete, jaliliani janga'unu. Sikutji re ngoi re ngowa'a re dano! Saro, saro, saro!

(Heil, geluk, zegen! wordt gemaakt! Het eind naar Batavia landwaarts, aangaan bij den vorst van Batjan, weet de beteekenis niet (is nutteloos), aankomen geen doel. Doen vervoegen bij den vorst van Tidore, weet de beteekenis niet, niet in staat te dienen. Opheffen (stellen onder) tot den vorst van Ternate, niet in staat te dienen, weet de beteekenis niet (is doelloos). Opheffen tot de groote baai, de 4 dorpen van Talai en de 5 baaien, weet de beteekenis niet, niet in staat te dienen, aankomen geen grenzen. Doe terugkeeren mijn vader en grootvader, zij dienen, zij in staat zijn. Doe afdalen met mij, met mijn kinderen, met mijn kleinkinderen! Heil, geluk, zegen!)

Onderwijl draait de kalifa het takje in de rondte, totdat het breekt, waarna de omstanders erop aanvallen om een blaadje te kunnen bemachtigen waarmede men het lichaam inwrijft, teneinde de z.g. barakati (zegen) deelachtig te worden. Een van de goeroes of de kalifa neemt de tjempakabloem uit het 
kommetje met de gekruide olie en bestrijkt daarmee de lichamen van de candidaat-dansers. Elk hunner bindt om zijn hoofd een nog niet tot vrucht gezetten tros van den areekpalm, terwijl hun oogen worden ingesmeerd met het helsche vocht uit de groote schaal, bestaande uit geneeskrachtige kruiden, zeewater, spaanschen peper, teneinde hen "helderziend» te maken. Onderwijl bestrijkt de kalifa hen met den areektros uit den schotel. Sommigen spannen al hun wilskracht in om te blijven staan, terwijl het bijtende vocht in hun oogen zijn werking doet; anderen vallen op den bank, waarna hun ledematen langzamerhand beginnen te trillen. Intusschen hebben trommen en bekkens niet opgehouden met hun oorverdoovende muziek de spanning, waarin ieder verkeert, te verhoogen en thans beukt men nog harder, in wilder tempo, elk der tot den djini-dans gewijden uitnoodigend den dans te beginnen. "Kom in! vaar in!» roept men den djini toe en zie daar begint de kalifa reeds te dansen en eenige goeroes naast hem met gesloten oogen en de salái of de djini-dans heeft een aanvang genomen. Harder slaan de reuzentrommen en hooger klinken de groote en kleine gongs in helsch lawaai en daar tusschen door het stampen der dansende voeten als zoovele slagen van zware vlegels op een hollandschen dorschvloer. De dansers krijgen het warm, het zweet gutst hun langs het gezicht, de oogen tranen van het helsche vocht, slap bungelen de armen langs het dansende lijf, op en neer, als marionetten op de maat der beukende trommen. "Kom in! vaar in!» En zie de djini laat niet lang op zich wachten. De kalifa kan niet meer. Zijn dans wordt minder krachtig. Hij begint te wankelen en ook de goeroes zijn uitgeput: de djini is ingevaren! Zoodra de moerids dit merken, snellen zij toe en vangen de wankelende dansers in hun armen op en leggen hen op den bank, want zij zijn "voorname lieden», die opgevangen moeten worden en niet zooals de leerlingen op den grond mogen vallen. Ook de leerlingen probeeren te dansen, maar die de kunst nog niet verstaan of geen kracht genoeg bezitten om weerstand te bieden aan het bijtende goedje, dat hen in de oogen is gesmeerd, vallen uit en doen niet meer mee. Onderwijl heeft men zich aan tafel gezet en begint men te eten. Het is boboso (pamali, taboe) op den eersten avond groote vischsoorten te eten. De geesten zouden anders kunnen denken, dat men in goeden doen was, vandaar dat de maaltijd begint 
met kleine vischjes, welke men schier dagelijks kan bekomen, z.g. "armelui'skost»: ngafi of make. Daarna begint men weer te dansen of te zingen op maat van trom en gong en zoo wordt het feest voor den djini, den beschermengel, 3 dagen en 3 nachten voortgezet. De vrouwelijke moerids worden door hun eigen sekse in al de geheimen van de djini-vereering ingewijd.

$\mathrm{Na}$ afloop van het djini-feest, waarbij eenige moerids tot medium zijn gepromoveerd, gaat men gezamenlijk onder trom en gonggeklop naar zee of naar de rivier, waar men zich gaat baden. Dit bad nl. reinigt allen van booze invloeden. De goeroes, die de moerids tot "ingewijden» moeten maken, slaan hen met den areektros en maken hen "rein». Daarna keert men terug naar de kaseba, waarna nog eens met frisschen moed gedanst wordt.

Op den $4^{\text {en }}$ dag gaat men in processie, evenals op den $1^{\text {en }}$ dag, zeewaarts ten einde weer sóudu (medicijn) te gaan halen, ditmaal voor de vereering van de in het afgeloopen jaar overledenen. Deze tocht wordt genoemd ori olana.

De afgestorvenen van het verloopen jaar zijn nog niet in de ómenge ma kam (resp. gam) d. i. dorp der geesten, aangekomen, doch verblijven nog in een doorgangsplaats, e. s. v. "vagevuur", genaamd djodjaga ma kam (resp. gam), het dorp van den bewaker, aldus genoemd naar den bewaker van de geesten der afgestorvenen, die zelf de didiái madutu, de "ware (rechte, eigenlijke) maker» genoemd wordt, omdat diens werk bestaat in het geschikt maken der geesten voor de verhuizing naar het geestendorp. Hij laat daartoe zijn geestenvolkje zwaren arbeid verrichten en is karig in het verstrekken van voedsel, zoodat 'de geesten doorloopend honger lijden. Vandaar dat de nabestaanden de afgestorvenen eenige dagen lang van allerlei heerlijk voedsel zullen voorzien, opdat deze weer nieuwe kracht zullen ontvangen om den moeilijken weg af te leggen naar de ómenge ma kam.

In elk huis, waar iemand in het afgeloopen jaar gestorven is, wordt een houten pop gemaakt, ${ }^{1}$ welke versierd wordt met een rood jakje, dat met goud- of zilvergalon is afgezet. Deze

1 Zooals in de dorpen van de dji'o (baai van Saoe). In de andere, als Talai en overige k-sprekende dorpen, vervangt men de houten pop door een gekleurde vlechtmat, welke aangekleed wordt op dezelfde wijze als de houten pop. (Afb. 10 stelt een nog niet versierde pop voor.)

Dl. 68. 
pop wordt met allerlei gouden, zilveren en koperen sieraden omhangen, terwijl verschillende gerechten daarvoor uitgestald worden, als rijst, kip, kokosnoten, arensap, eieren van kippen of van den "hoopenvormer» (der Megapodius of loophoender, Eulipoa Wallacei, hier geheeten mamoa), pisangvruchten, tabak, sirih-pinang-ingrediënten, een paar stukken rood of wit katoen, kleeren, enz. Op dien vierden dag begint men met pula ómenge $o$ óromo, d.i. eten geven aan de geesten der afgestorvenen. Deze maaltijd wordt genoemd de óromo lámo'o, de groote maaltijd. De goeroes of mediums leggen zich neder (ngidu, slapen) op een rustbank, worden overdekt met een sarong en beginnen te trillen, ten teeken, dat zij in somnambulistischen toestand geraken en zich in verbinding stellen met de geesten der afgestorvenen, die in de djodjaga ma kam verblijf houden. Hij noodigt hen uit aan te zitten en gebruik te maken van het eten, dat de nabestaanden hen hebben voorgezet. Deze plechtigheid herhaalt zich nu de eerstvolgende dagen, terwijl met den $7^{\text {en }}$ of $9^{\text {en }}$ dag, al naar men tevoren den duur bepaald heeft, het feest besloten wordt door een inderdaad schitterend feest, de z.g. tjiawa (Tern. legu) d.i. de maskerade. De avond tevoren heeft de sado plaats, d. i. het begeleiden van de geesten uit de djodjaga ma kam naar de ómenge ma kam, dat weer dọor den gomátere (medium) in somnambulistischen slaap moet geschieden.

Zoodra de zon is opgegaan zijn allen, van klein tot groot, in de weer om alles in gereedheid te brengen voor de honderden gasten uit andere dorpen, die op dien dag de maskerade zullen bijwonen. De geesten der afgestorvenen hebben nu hun deel gehad, zijn met nieuwe krachten toegerust om den tocht naar het geestendorp te volbrengen. Men is dus verheugd over den goeden afloop en wil nu deze inspannende dagen besluiten met een dag, grooter dan de voorafgaande dagen. Reusachtige hoeveelheden rijst, visch en saus worden gekookt, koekjes en zoetigheden klaargemaakt, lange bamboes worden gevuld met arensap (tjádu'u) en midden op het dorpsplein een lange tafel aangericht voor de gasten, die als een groot priëel versierd wordt met frissche, gespouwen bladeren van den arenpalm (wowe). De opgedischte spijzen worden met bloemen en vlechtwerk versierd (zie afb. 1). Aan een hoogen vlaggestok wordt de hollandsche driekleur geheschen, terwijl de sasádu (dorpshuis) 
versierd worden met de vlaggetjes (padji-padji) welke vroeger door den Sultan van Ternate geschonken zijn als teeken van het bizondere privilege aan de Saoe'sche dorpen toegestaan. Dit privilege bestaat hierin, dat de stam der Saoeërs gerechtigd is de tjiawa, de maskerade, uit te voeren. Het is interessant de menschen op dien morgen bezig te zien. Hier haalt men uit de kisten de mooie sarongs, gewaden en uniformen tevoorschijn. Daar is men bezig op een speciaal daarvoor gemaakten houten kop de stijve hoofddoeken te vouwen en die met een kokette punt aan den linkerkant op het hoofd gezet wordt. Het huis van het Hoofd is extra versierd en de gastenbanken zijn met de mooiste familiematten en hoofdkussens belegd. Langzamerhand komen de gasten opdagen uit andere dorpen, mannen, vrouwen en kinderen, allen in feestdos. De ongehuwde, jonge vrouwen zijn werkelijk smaakvol gekleed. Het zwarte haar met kokosolie gladgestreken en met witte en roode bloemetjes versierd; lange, zilveren knoppen in het oor; gekleed in een blauw baadje en sarong, welke belegd zijn met ontelbare, blinkend metalen loovertjes, terwijl onder het baadje een snoer met belletjes is gebonden, die bij elke lichte beweging rinkelen De hoofden zijn meest gedekt met helgele of roode doekjes.

De trommen en gongs, welke van den eersten dag aan niet gezwegen hebben, worden nu met frisschen moed geslagen als om de deelnemers aan den sepa-dans uit te noodigen hun rondgang te beginnen. Een 5-tal mannen komen verlegen te voorschijn. Gekleed in lange, veelkleurige, hemdvormige jassen met een stok in de hand, over welks knop een witte of gekleurde doek gehangen is, gaan zij schoorvoetend naar het midden van het dorpsplein, scharen zich rondom den vlaggestok, maar de een voor den ander durft de eerste sepa niet te wagen, bevreesd, dat hij de maat van den trom nog niet te pakken heeft, een misstap zal doen en dientengevolge uitgelachen zal worden (afb. 2). Daar vermant er zich een en zet de sepa in: den rechtervoet voorwaarts en tegelijkertijd den stok neergezet en den linkervoet opgeheven; fluks den linker neergezet, één pas met den rechter achteruit, het lichaam met den rug naar links gedraaid en dan met een sierlijken zwaai den linker den dubbelen afstand vooruit; weer den rechter één pas voorwaarts en achteruit in snel tempo, terwijl telkens als de linkervoet zijn zwaai neemt, de linkerhand het lange kleed openhoudt 
en dat met elke beweging gracieus opent en weer sluit (afb. 5). $\mathrm{Nu}$ begint ook de tweede en de derde en zoo vervolgens alle 5 mannen, totdat de anderen, aangemoedigd door het succes der eersten, zich bij den kring aansluiten. Waar de Saoe'sche adat verbiedt zich in het dagelijksch leven te tooien met kleeren of sieraden, welke alleen hoogergeplaatsten mogen dragen, daar is op dezen dag ieder gerechtigd zich voor te doen als de vorst (olana), de rijksbestierder (djougugu), een hadji, officier, e. d. Zelfs hebben enkelen een pajong boven het hoofd (afb. 3 en 4 , toevallig een damesparasol!). De omstanders juichen de spelenden toe, die zonder vermoeienis in de geweldige tropenzon, welke nog maar nauwelijks over de middaghoogte heen is, hun spel voort zetten. Er zijn er onder, die het sepa-spel voor de zooveelste maal uitvoeren, bedreven zijn in de rhytmische passen en zoo nu en dan de omstanders aanzien als om een toejuiching te ontlokken. Anderen, en dat zijn de beginners, probeeren telkens tevergeefs in den kring mee te doen, doch kunnen den sepa-dans niet te pakken krijgen. Zij zijn het voorwerp van spot en moeten menigen kwinkslag van de toeschouwers verduren. Af en toe verdwijnt er een uit den kring, laaft zich aan het arensap, gaat weer naar zijn woning en komt na korten tijd terug met een nog schitterender gewaad. Degenen, die op dien dag den "gebraden haan» willen uithangen, verwisselen wel 5 of 6 maal van costuum, zooals de twee voorsten op afb. 5. Op deze foto ziet men ook duidelijk de twee witte kalkstippen (tache de beaute!) op de mondhoeken aangebracht, welke door het hevige transpireeren telkens opnieuw moeten aangebracht worden. De Saoeërs zijn over het algemeen welgesteld, aangezien zij een arbeidzaam volk zijn en groote rijsttuinen aanleggen. Er zijn er onder die wel een $f 120$ voor hun maskerade-kleedij besteden.

Het sepa-spel is alleen voor de mannen. De vrouwen moeten meest voor de consumptie zorgen en voorzoover dit niet het geval is, vermaken zij zich met de jonge meisjes, van wie een deel als prinsessen gekleed zijn en die hand aan hand, statig en stijf, met neergeslagen oogen, voetje voor voetje in de rondte loopen ( $a f b$. 6). Andere mannen en vrouwen spelen het z.g. modin-spel. Met een doek over het hoofd naderen zij de toeschouwers, veranderen hun stem, steken - wanneer het een "gewoon burger» geldt - een of twee vingers op ten 
teeken, dat men een of twee centen begeert. Geldt het een "welgestelde», dan steken zij 5 tot 10 vingers op, teneinde zooveel centen te ontvangen als hun vingers aanwijzen. Weer anderen hebben het geheele lichaam gewikkeld in een zwarte vacht, n.l. het haarnet van den arenpalm en een mombakkes, tjakaiba, van een uitgesneden en beschilderden bladsteel van den sagopalm voor het aangezicht gebonden, terwijl zij de dolste grimassen uitvoeren tot groot vermak van de honderden toeschouwers. In hun hand houden zij een bamboe-kokertje, waarin een sleuf is gemaakt om daarin de geldelijke belooningen voor hun grappen te laten glijden. De grappen dezer mannen zijn nog al pikant en op het kantje af, aangezien enkelen onder deze vermomming de door de adat voorgeschreven publieke eerbaarheid overschrijden door allerlei toeren te verrichten met een kunstmatig aangebracht, reusachtig schaamdeel, wat slechts dient om de hilariteit van de toeschouwers, die dien dag door het dolle heen zijn, te vergrooten (afb. 7.) Andere grappenmakers probeeren deze vermomde mannen van achteren onhoorbaar te naderen, een brandenden lucifer te steken in de zwarte, als pek brandende vacht, waarop men hen toeroept: tjakaíba! ngani wala ana dutáudu! (Mombakkes, ze steken je huis in brand!). Fluks laat dan de belaagde zich achterover op den grond vallen en rolt zich heen en weer, tot het vuur is uitgedoofd. Een inderdaad gevaarlijk spelletje! Nog anderen, hetzij mannen of vrouwen, houden de toeschouwers een groote kom voor, gevuld met arensap, waarin men een paar centen moet werpen, ten teeken, dat die kom ad fundum moet geledigd worden door hem of haar, die deze vasthoudt. Ook vermaken mannen en vrouwen zich met het z.g. roge (Mal. ronggeng), dat minder een dans is dan wel een spel, waarbij het lichaam zich in allerlei sierlijke bochten wringt. Op de maat van de trom heft men de armen met de handen tegen elkaar gelegd naar boven, maakt met den mond en tanden geluiden als een koetsier, die zijn paard tot loopen aanzet, blijft met de voeten op dezelfde plaats staan en wringt armen en lichaam in allerlei sierlijke bochten, waarbij elke spier in actie is. De kunstenaars onder dezen worden door de omstanders luide toegejuicht tja! tja! tja! met handengeklap op de maat van de trom.

Het succes van den middag is zeker wel, wanneer tusschen de dansende en joelende menigte de z.g. gïidi lamo'o, "de 
grooten, voornamen», te voorschijn komen. Deze zijn de als "officieren» verkleeden. Oude kurassiers- en schuttersuniformen, welke men tegen hooge prijzen gekocht heeft van slimme Arabieren te Ternate, maken de bewondering gaande van de menigte. Bij deze kleeding vertoonen sommigen de meest zonderlinge kombinatie. Zoo draagt de man op afb. 9 links, bij zijn uniform een onderbroek met bandjes om de enkels vastgemaakt, waarschijnlijk afkomstig van een Europeanen-vendutie op Ternate, terwijl diezelfde man blijkbaar geen raad weet met zijn overcomplete epauletten en daarmede borst en buik behangen heeft. Deze officieren doen niet mee aan het sepa-spel, doch loopen met rinkelende sabel, hevig transpireerende onder het gewicht dezer europeesche kleedij, het dorpsplein rond, op den voet gevolgd door kinderen en volwassenen, die om beurten het schitterend gewaad dezer "voorname lieden» bewonderen. De feestvreugde heeft nu haar hoogtepunt bereikt. De dorpshoofden glunderen genoeglijk over het welgeslaagde feest en zijn onuitputtelijk in het aan tafel noodigen der gasten. Rijkelijk stroomt de tjadu'u (arensap) om de dorstige kelen te laven en de vrouwen brengen steeds nieuwe voorraden rijst en visch op de gastentafel, waaraan ieder om beurten kan aanzitten.

De zon begint achter de hooge boomen te verdwijnen. Het loopt tegen half zes. $\mathrm{Nu}$ wordt de kroon op het feest gezet. De daartoe aangewezen mannen gaan de huizen binnen, waar de versierde poppen (dodaro) staan, welke de in het afgeloopen jaar overledenen moeten voorstellen, brengen die naar buiten en onder oorverdoovend gejoel en gezang begint men opnieuw den sepa-dans, ditmaal om ook de afgestorvenen daarin te laten deelen. Het is een aangrijpend gezicht dezen laatsten rondedans te zien onder oorverdoovend geluid van al de reuzentrommen, waarop met een laatste krachtsinspanning gebeukt wordt. Tegen zonsondergang heeft dit spel een einde genomen. De trommen zwijgen voor een oogenblik en voordat de menigte uiteengaat, zetten de dorpelingen zich om een lange tafel, waarop niets anders gezet wordt dan een groote schotel, gevuld met medicijn (soudu), bestaande uit: geneeskrachtige gestampte wortels en bladeren, gekruide kokosolie, waarin weer een jonge, nog niet ontloken vruchtentros van den areekpalm gelegd is. Naast dezen schotel staat een flesch met andere medicijn, in den hals waarvan ook een areektros gestoken is. Voorts een bord, waarop 
sirih-pinang-ingrediënten en eindelijk twee stukken wit katoen. Neergezeten beginnen enkelen op de maat van een kleine trom te zingen (njiati), welk gezang gewijd is aan de afgestorvenen en ongeveer een tien minuten duurt. Daarna ontvangt ieder der aan tafel zittenden en ook de omstanders de sirih-pinang om te pruimen als teeken van gemeenschappelijk besluit van het welgeslaagde doodenfeest. De twee stukken katoen worden weer opgeborgen, om het volgend jaar op dezelfde wijze weer op tafel gelegd te worden bij de sluiting van het doodenoffer. Het doodenfeest is nu afgeloopen. De schotel en de flesch geneeskrachtige kruiden worden nu door een man het dorp rondgedragen, terwijl hij bij elke woning halt houdt en met den in de medicijn gedrenkten jongen pinangtros de benedendorpels van alle woningen besprenkelt, teneinde de huizen tegen booze invloeden te vrijwaren.

De meeste bezoekers uit andere dorpen keeren nu huiswaarts, maar de feestvierders hebben nog niet genoeg genachtbraakt, want wel zijn thans de geesten der afgestorvenen verzorgd, doch de goeroes en degenen, die geholpen hebben het feest te doen slagen, komen nu aan de beurt. In alle huizen, waar de poppen der afgestorvenen staan, houdt men een collecte, welke na afloop van het feest verdeeld wordt onder hen, die als helpers deze dagen gediend hebben. Adat is, dat elk dan niet minder dan 8 ct. per hoofd ontvangt. Zoodra de bezoekers verdwenen zijn, komen de dorpelingen en de familieleden van andere dorpen samen in de sasadu (gemeentehuis) waar tevoren de tafel met allerlei spijzen gedekt is. Weer klinken de reuzentrommen en gongs den geheelen nacht door, waarin men wederom overvloedig drinkt en eet, afgewisseld door de geliefkoosde beurtzangen, krijgsdansen (sara, Mol.-Mal. tjakalele), en roge (Mal. ronggeng). Den geheelen nacht fuift men er nog eens op los, zoodat men bij het aanbreken van den dag een gezelschap bijeen kan zien met holle oogen en schorre stemmen, verward dooreenschreeuwende. Hier liggen er een paar te slapen, daar zijn de magere honden bezig een aanval te wagen op de borden van de slapers, welk waagstuk hen in aanraking brengt met een of ander voor de hand liggend projectiel in den vorm van een blok hout of een kokosbast, dat van de zijde der half wakenden komt aanzeilen. Jankende en druipstaartende verwijderen de stumperds zich onder de tafel, waar ze de gevallen 
«brokskens» trachten te bemachtigen, inzooverre een schop of een trap hen dat niet belet. Alhoewel nu de genoodigden uit andere dorpen terugkeeren, is het nafeest nog niet afgeloopen. Nog één nacht gaat men met fuiven door, zooals het heet "tot afscheid», want na dien allerlaatsten nacht gaat men successievelijk weer terug naar de dóusu (bijdorpen in de tuinen) om dan eerst weer over een jaar in het eigenlijke dorp terug te keeren en op dezelfde wijze het djini- en geesten-offer te vieren.

Eenige weken na het feest is het dorp weer als uitgestorven en het onkruid tiert weer welig.

Sedert een paar jaar tracht het Gouvernementsbestuur hierin verandering te brengen en de menschen te bewegen hun dorpen te bewonen, doch door afwezigheid van permanent bestuur hebben deze maatregelen weinig succes. Van alle distrikten op Halemahera is in het distrikt Saoe het meest de invloed merkbaar van den Sultan van Ternate. De meeste Saoeërs kan men in uiterlijk en kleederdracht, bij feesten en in het dagelijksch leven, moeilijk van de Ternataansche Mohamedanen onderscheiden. In afb. 12 is de schrijver van den Sultan van Ternate afgebeeld. De Saoe'sche Hoofden zijn gelijk gekleed. De meesten hebben het hoofd geheel kaal geschoren en hebben veel gebruiken van de Mohamedanen overgenomen, wat vooral uitkomt tijdens de feesten. Velen der Saoeërs beschouwen het eten van varkensvleesch als boboso (pamali, taboe), laten zich besnijden, en in de meeste dorpen kan men aan het einde der Moh. vasten ook de z.g. ela-ela zien, d. i. de voor elke woning geplaatste pisangstam, waarop des avonds gomcopal gebrand wordt. 


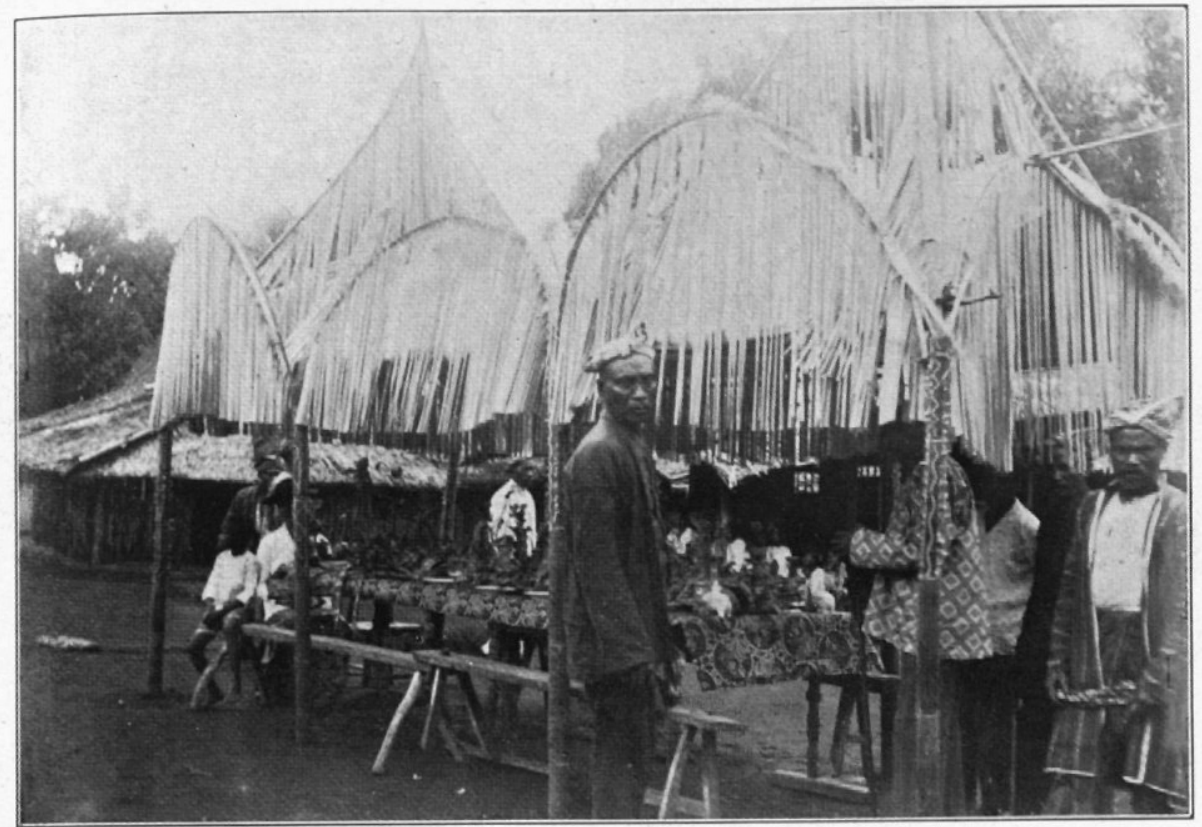

a

2

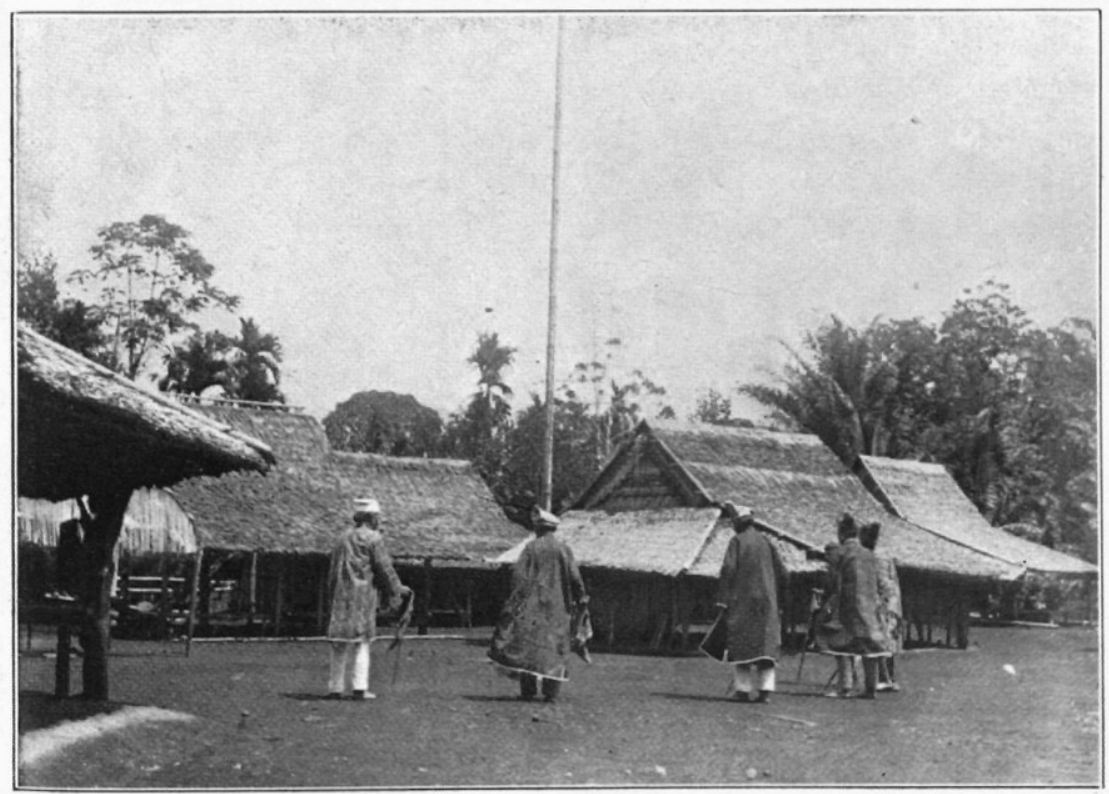




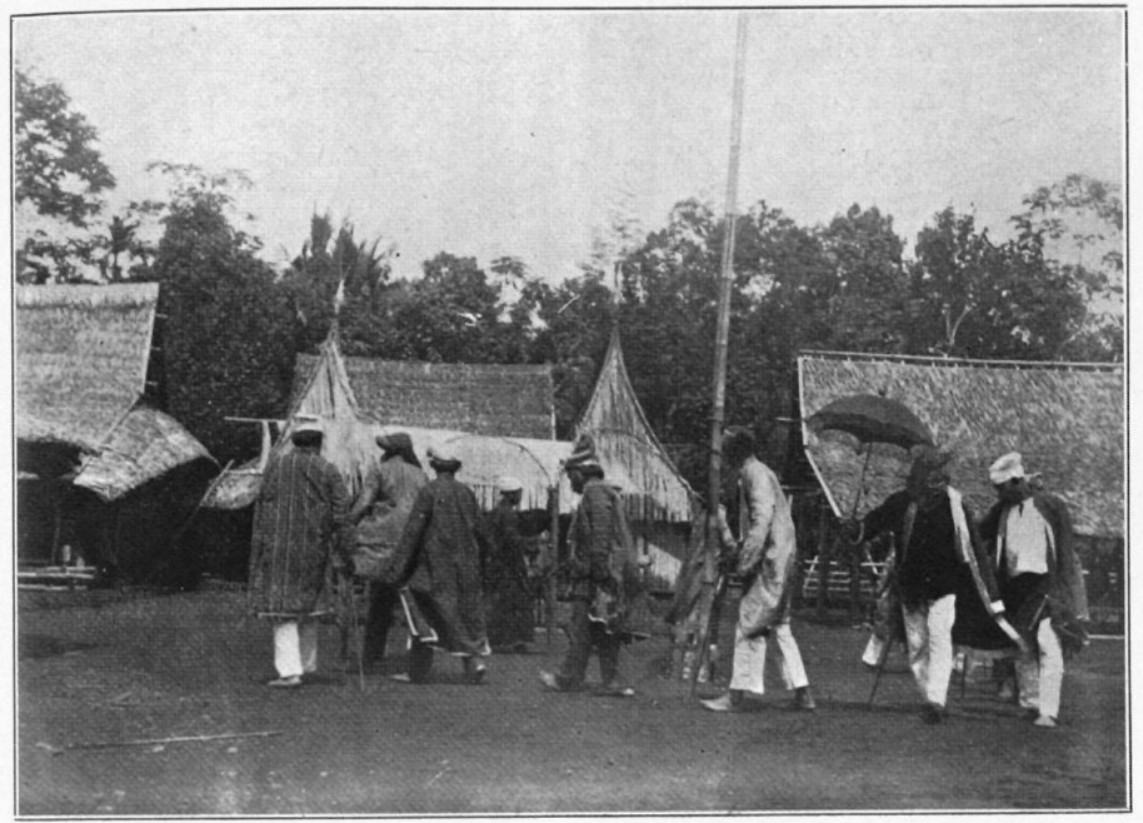

4

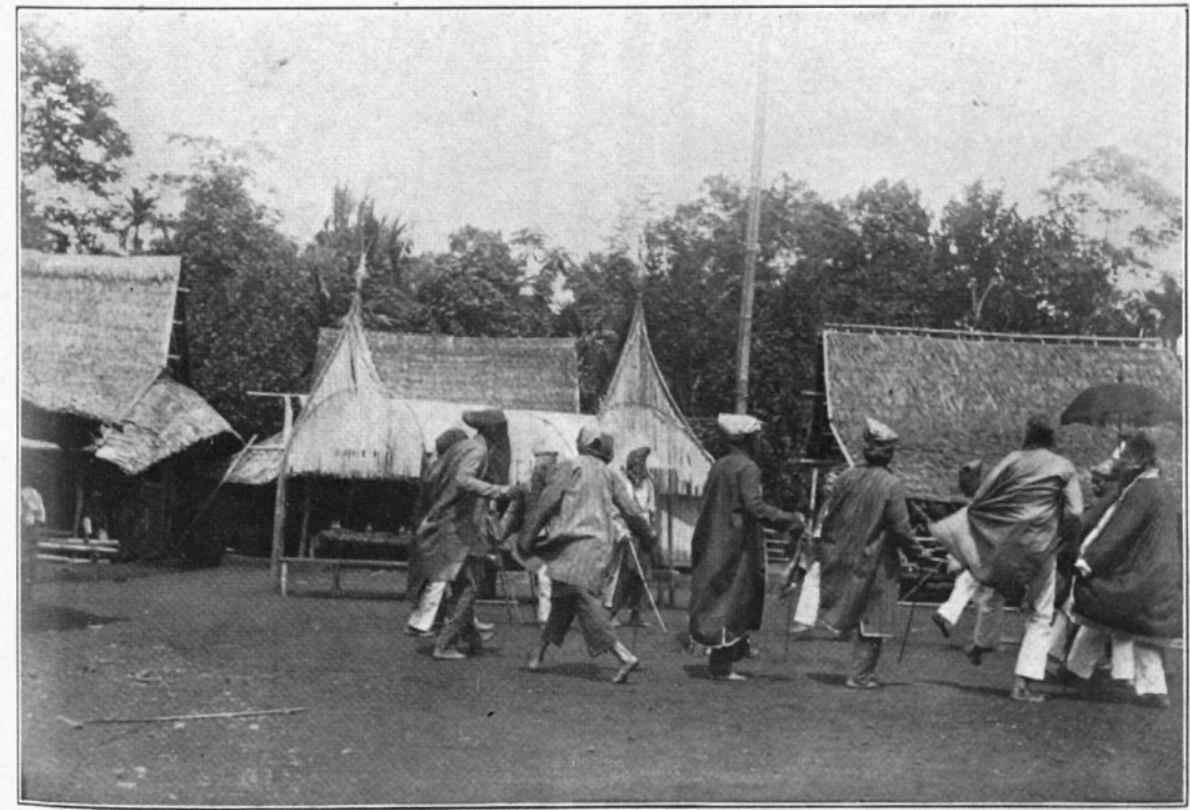




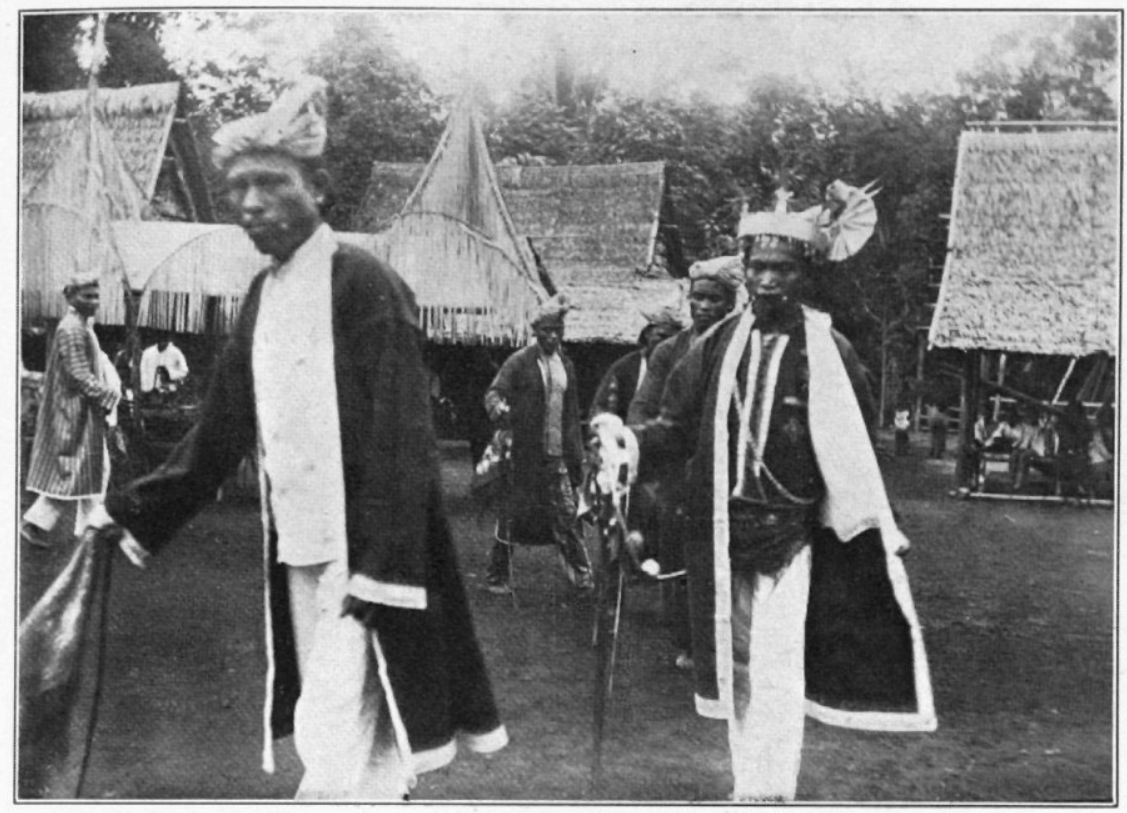

6

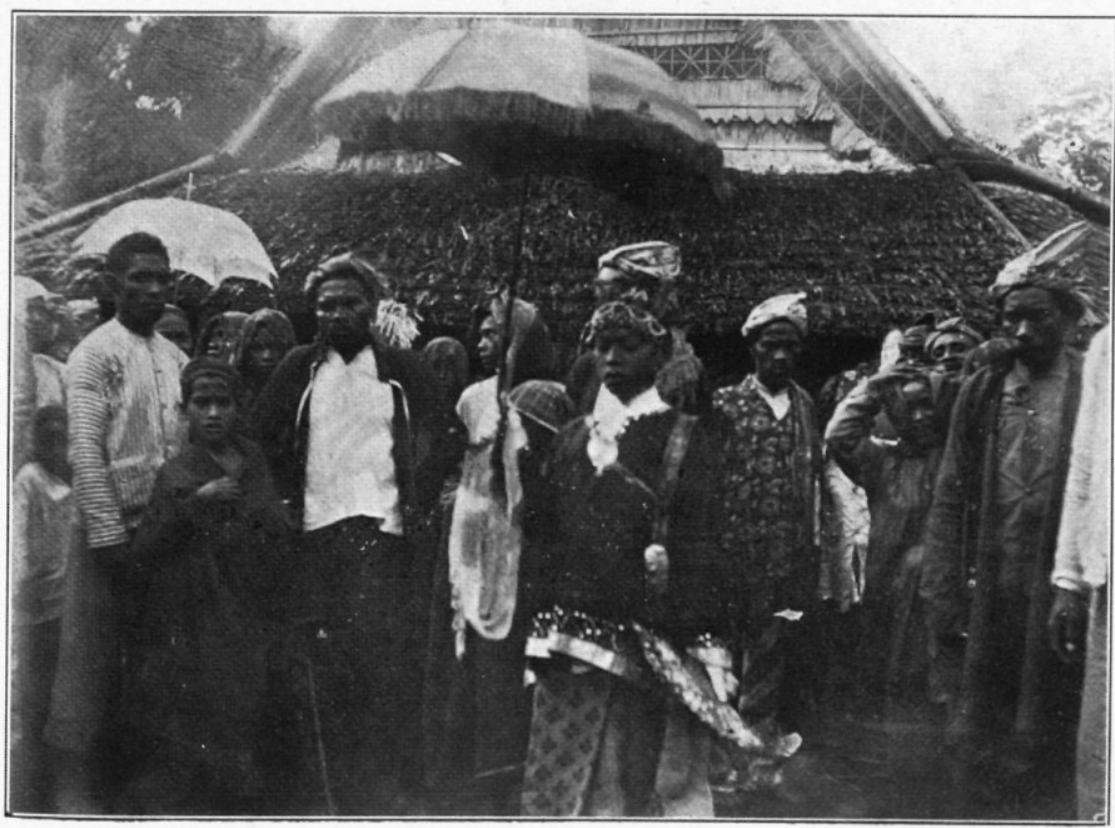



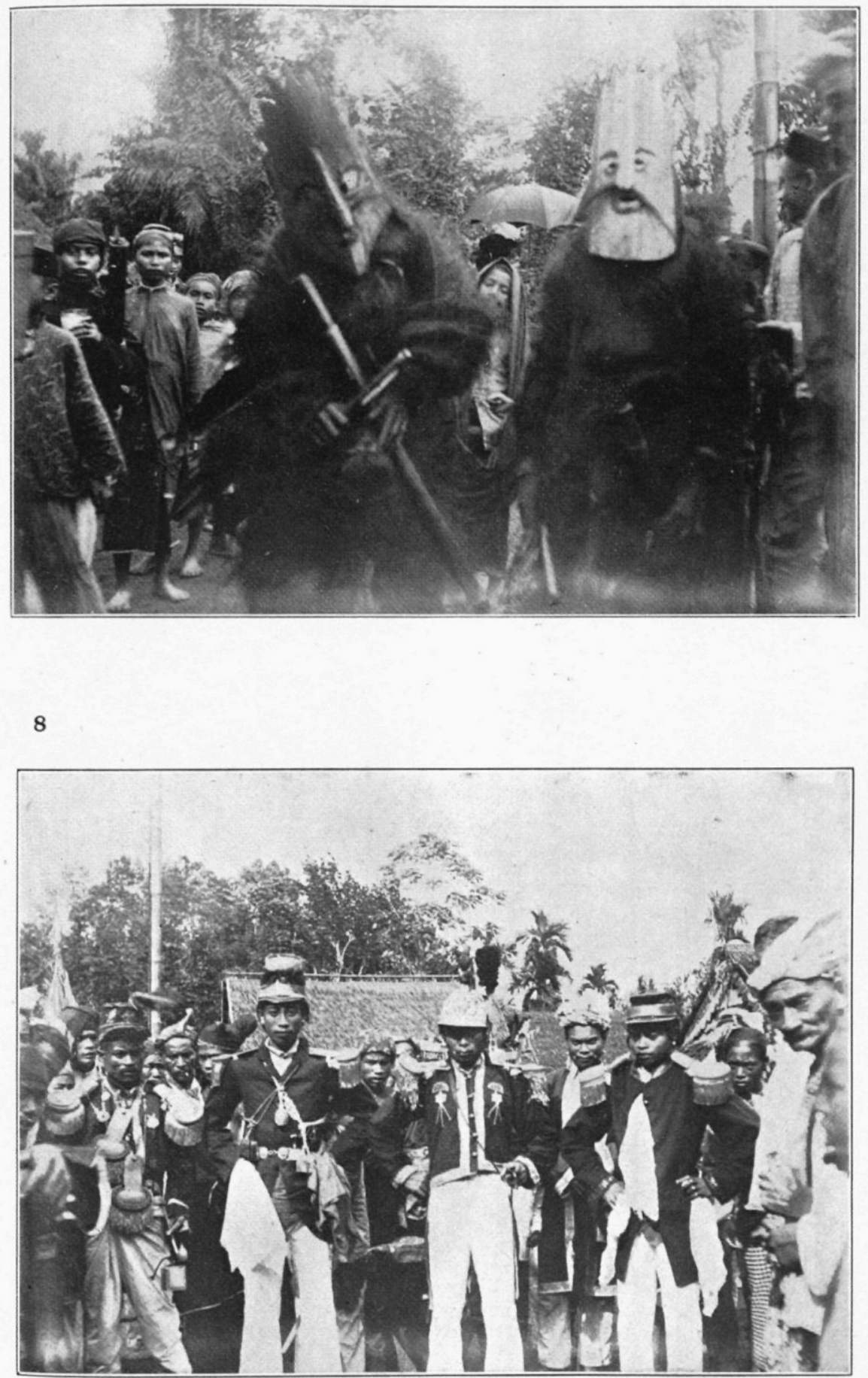


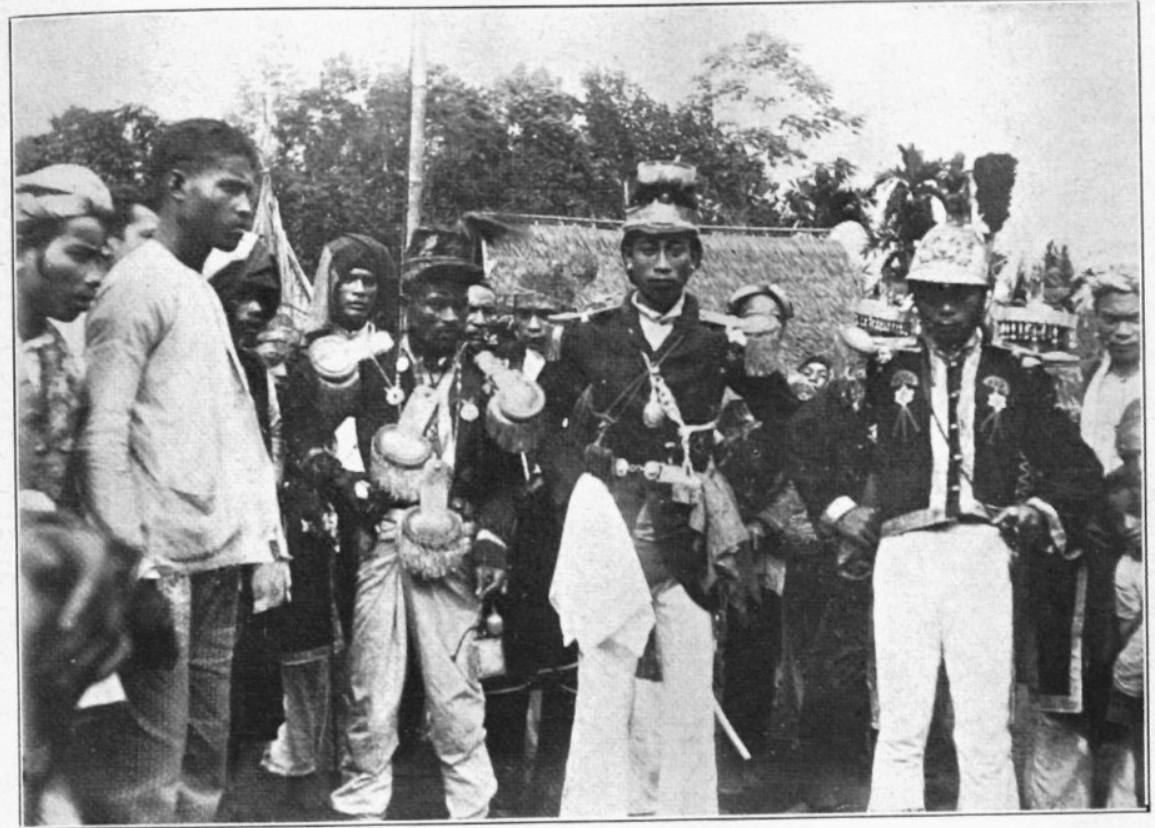

10

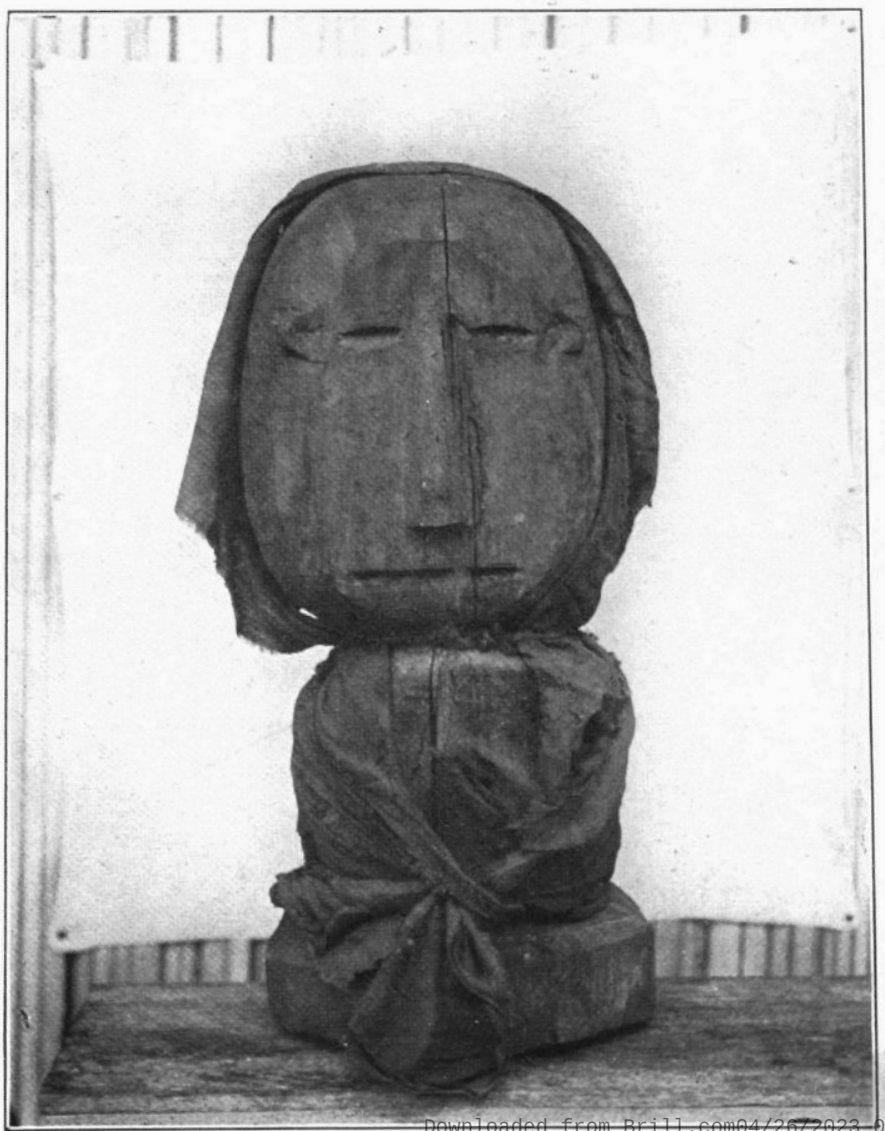




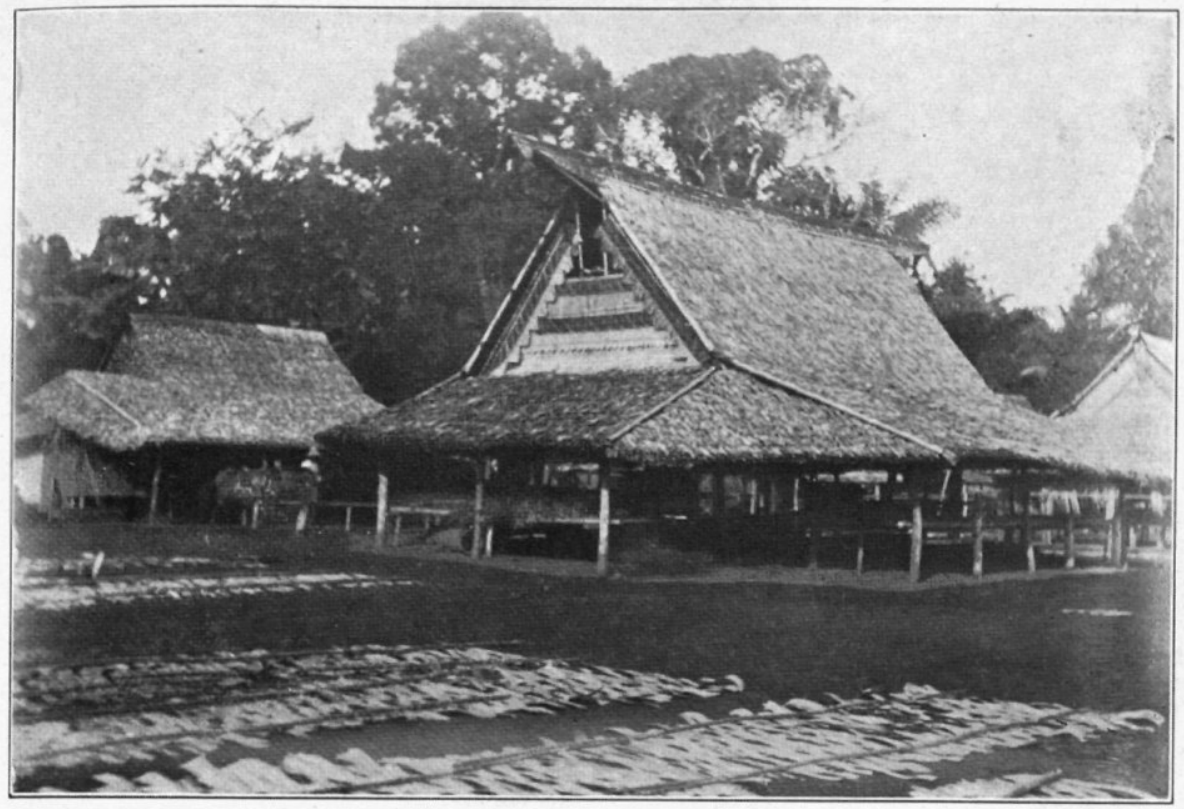

12

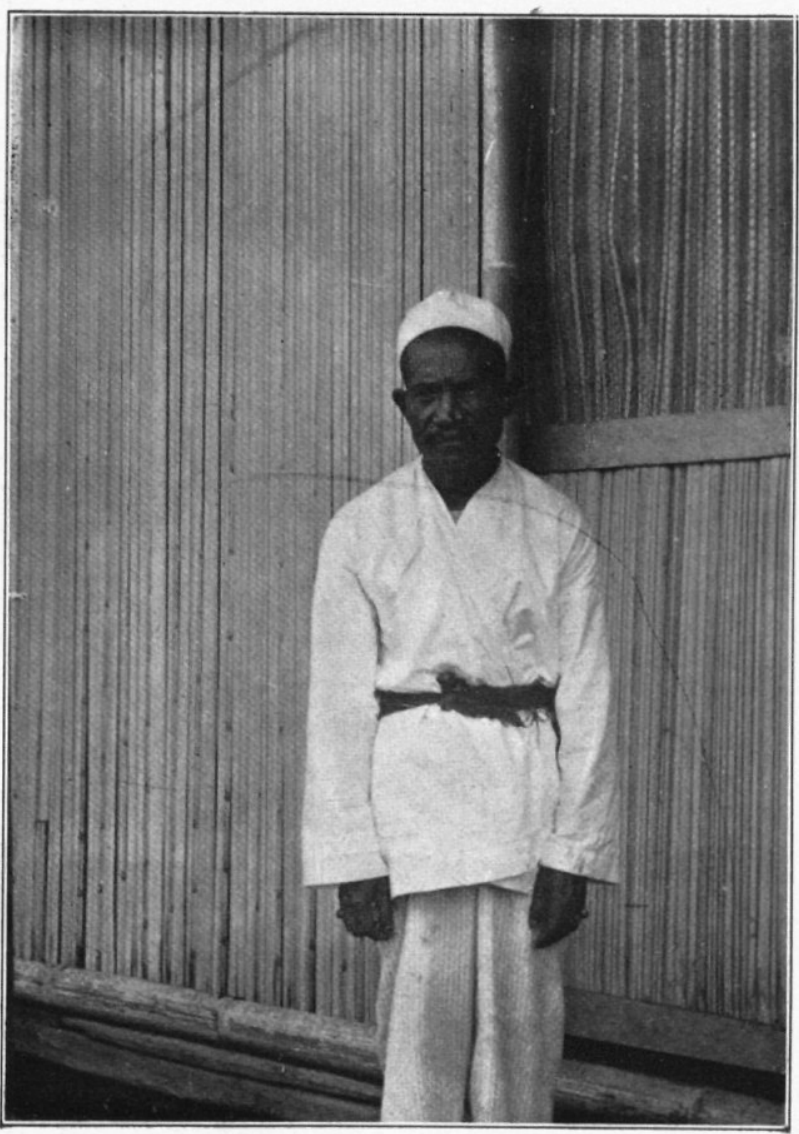

Downloaded from Brill.com๑4/26/2023 06:40:23AM 